\title{
SIMULASI ALIRAN FLUIDA PADA RUMAH TURBIN VORTEX DENGAN 5 VARIASI LUBANG BUANG MENGGUNAKAN COMPUTATINAL FLUID DYNAMICS
}

\author{
Budiman Yudha Simbolon ${ }^{1}$, Syahril Gultom ${ }^{2}$, Zulkifli Lubis ${ }^{3}$, A. Husein Siregar \\ ${ }^{1,2,3,4}$ Departemen Teknik Mesin, Fakultas Teknik, Universitas Sumatera Utara \\ E-mail : budimanyudhasimbolon@gmail.com
}

\begin{abstract}
ABSTRAK
Indonesia sampai saat ini masih mengalami permasalahan tentang energi listrik. Permasalahan tersebut terdiri dari jaringan listrik, daerah pedesaan yang jauh dari kota, dan sumber energi fosil yang hampir habis. Pembangkit listrik tenaga air merupakan salah satu pilihan dalam memanfaatkan sumber energi terbarukan. Turbin Vortex adalah salah satu jenis turbin mikrohidro yang menggunakan pusaran air sebagai penggerak sudu. Turbin Vortex mempunyai ketinggian air yang relatif rendah antara $0.7 \mathrm{~m}$ sampai $2 \mathrm{~m}$. Turbin ini baik digunakan pada aliran sungai. Untuk itu dilakukan analisa dan simulasi secara numerik dengan bantuan software Ansys FLUENT 14.0. Simulasi Computation fluid Dynamic (CFD) dapat menganalisa atau memprediksi aliran fluida yang ada pada rumah turbin vortex. Proses tersebut meliputi Pre-processing, Solving, dan Postprocessing. Analisis dilakukan pada aliran tiga dimensi (3D), transient, turbulen dan incompresible. Variabel yang digunakan untuk dianalisa adalah diameter lubang buang air. Hal tersebut terdiri dari lima ukuran $3 \mathrm{~cm}, 5.5 \mathrm{~cm}, 8.5 \mathrm{~cm}, 10.5 \mathrm{~cm}$ dan $16 \mathrm{~cm}$. Dari hasil analisa simulasi didapat daya air paling maksimum pada diameter lubang buang 16 $\mathrm{cm}$, yaitu 24.24680432 watt dengan debit $0.008253662 \mathrm{~m}^{3} / \mathrm{s}$ dan head $0.3 \mathrm{~m}$.
\end{abstract}

Kata kunci: Energi, Vortex, CFD, Ansys, Turbin Vortex, Lubang Buang

\section{PENDAHULUAN}

Banyak daerah di Indonesia yang mengalami permasalahan tentang energi listrik. Hal tersebut dikarenakan jaringan PLN belum ada ataupun masih sangat terbatas. Daerah pedesaan sering menjadi tempat-tempat yang terisolasi dan bergantung kepada pemakaian energi tradisional yang tidak bisa diandalkan, seperti generator yang berbahan bakar minyak, kayu atau tabung LPG sebagai sumber energi yang digunakan untuk memasak, penerangan, serta kebutuhan listrik dasar lainnya. Solusi energi terbarukan menjadi jawaban terhadap permintaan kebutuhan pembangunan desa di Indonesia, serta mempromosikan solusi praktis dan berkelanjutan yang bisa langsung diadopsi oleh masyarakat pedesaan yang menjadi prioritas bagi bangsa Indonesia. ${ }^{[1]}$

Microhydro ataupun Picohydro yang biasanya memanfaatkan air terjun dengan head jatuh yang besar. Sedangkan untuk aliran sungai dengan head jatuh yang kecil belum termanfaatkan dengan optimal. Hal ini menjadi referensi untuk memanfaatkan aliran sungai dengan mengubahnya menjadi aliran vortex. Untuk itu perlu dilakukan berbagai penelitian dimana salah satunya adalah Computational 
Fluid Dynamics (CFD). Penelitian ini menggunakan software Fluent Ansys untuk melakukan simulasi-simulasi yang terjadi sebelum fabrikasi.

\section{TINJAUAN PUSTAKA}

Dalam dinamika fluida, vortex adalah sebuah daerah di dalam fluida dimana sebagian besar aliran bergerak memutar pada terhadap sumbu yang imajiner. Pola gerakan disebut aliran vortex.Vortex terbentuk oleh fluida termasuk cairan, gas, dan plasma. Beberapa contoh umum adalah lingkaran asap, pusaran air yang sering timbul pada gerakan perahu, angin pada badai dan tornado, atau sayap pesawat terbang. ${ }^{[2]}$

Secara umum, fenomena vortex terbagi atas dua bahagian yaitu :

1. Vortex Paksa / Vortex Berotasi adalah vortex yang terbentuk karena adanya gaya luar yang berpengaruh pada fluida.

2. Vortex Bebas / Vortex Tak Berotasi adalah vortex yang terbentuk karena fenomena natural, tidak terpengaruh oleh gaya dari luar sistem fluida, pada aliran inkompresibel, umumnya terjadi karena adanya lubang keluar. ${ }^{[3]}$

\section{Turbin Vortex}

Aliran sungai dengan head yang kecil belum termanfaatkan dengan optimal. Hal ini menjadi referensi untuk memanfaatkan aliran sungai dengan mengubahnya menjadi aliran vortex. Seorang Peneliti dari Jerman Viktor Schauberger mengembangkan teknologi aliran vortex (pusaran) untuk diterapkan pada pemodelan turbin air dengan memanfaatkan aliran irigasi yang kemudian diubah menjadi aliran vortex (pusaran), yang kemudian dimanfaatkan untuk menggerakkan sudu turbin. Gambar 1 menunjukan bentuk dari turbin vortex. Aliran vortex yang juga dikenal sebagai aliran pulsating atau pusaran dapat terjadi pada suatu fluida yang mengalir dalam suatu saluran yang mengalami perubahan mendadak. ${ }^{[4]}$

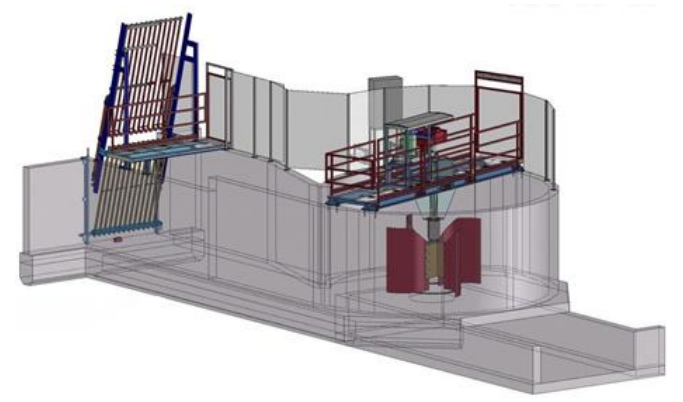

Gambar 1. Turbin Vortex

\section{Computation Fluid Dynamic (CFD)}

Computational Fluid Dynamics (CFD) adalah salah satu cabang dari mekanika fluida yang menggunakan metode numerik dan algoritma untuk menyelesaikan dan menganalisa masalah yang terjadi pada aliran fluida. Secara umum, CFD dipakai untuk memprediksi :

○ Aliran dan panas. 
- Transfer massa.

- Perubahan fasa seperti pada proses melting, pengembunan dan pendidihan.

- Reaksi kimia seperti pembakaran.

- Gerakan mekanis seperti piston dan fan.

- Tegangan dan tumpuan pada benda solid.

- Gelembung elektromagnetik.

Pada umumnya terdapat tiga tahapan yang harus dilakukan ketika melakukan simulasi CFD, yaitu

○ Pre-processing

Pre-processing merupakan langkah pertama dalam membangun dan menganalisis sebuah model CFD. Teknisnya adalah membuat model dalam paket CAD (Computer Aided Design), membuat mesh yang sesuai, kemudian menerapkan kondisi batas dan sifat-sifat fluidanya.

○ Solving

Solvers (program inti pencari solusi) CFD menghitung kondisi-kondisi yang diterapkan pada saat pre-processing.

- Post-processing

Post-processing adalah langkah terakhir dalam dalam analisis CFD. Hal yang dilakukan pada langkah ini adalah mengorganisasi dan menginterpretasi data hasil simulasi CFD yang bisa berupa gambar, kurva, dan animasi. ${ }^{[5]}$

\section{Fluent}

Fluent adalah program komputer yang memodelkan aliran fluida dan perpindahan panas dalam geometri yang kompleks. FLUENT merupakan salah satu jenis program CFD (Computational Fluid Dynamics) yang menggunakan metode diskritisasi volume hingga. FLUENT memiliki fleksibilitas mesh, sehingga kasuskasus aliran fluida yang memiliki mesh tidak terstruktur akibat geometri benda yang rumit dapat diselesikan dengan mudah. Selain itu, FLUENT memungkinkan untuk penggenerasian mesh lebih halus atau lebih besar dari mesh yang sudah ada berdasarkan pemilihan solusi aliran. ${ }^{[6]}$

\section{METODOLOGI PENELITIAN}

\section{Proses Pre-Processing}

a. Pembuatan Model

Pembuatan model dalam simulasi ini mengacu pada bentuk turbin vortex yang sebenarnya dan dapat dilihat pada gambar 2. 


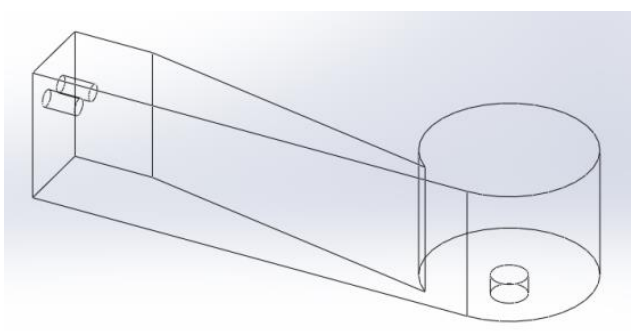

Gambar 2. Model Turbin Vortex

Pembuatan model CAT tersebut menggunakan software SolidWorks dan spesifikasi dapat dilihat pada tabel 1 .

Tabel 1. Spesifikasi CAD Turbin Vortex

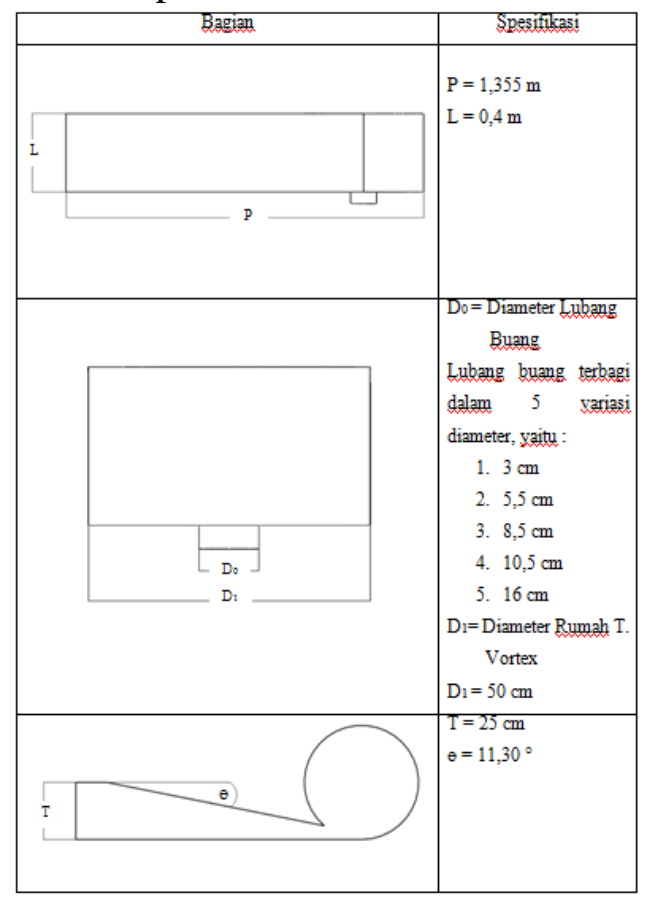

\section{b. Penentuan Domain}

Secara eksperimental, pengujian turbin vortex dilakukan dengan fluida air dimana aliran yang terjadi membentuk pusaran/vortex. Domain dari model turbin vortex ditunjukan pada gambar 3 .

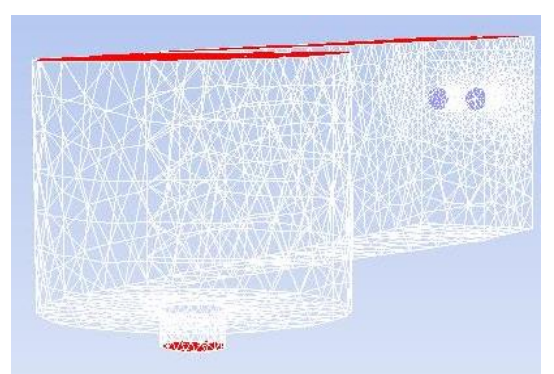

Gambar 3. Penentuan Domain 
Pada gambar diatas, domain/batas berada pada daerah yang telah ditentukan sesuai ukuran yang dibuat.

\section{c. Pembuatan mesh (meshing)}

Dalam proses pembuatan mesh, ukuran dan jenis mesh harus diperhatikan karena hal tersebut sangat mempengaruhi tingkat ketelitian dari hasil simulasi. Semakin kecil ukuran mesh, maka semakin tinggi tingkat ketelitian yang didapat namun semakin besar daya komputasi dan waktu yang diperlukan.

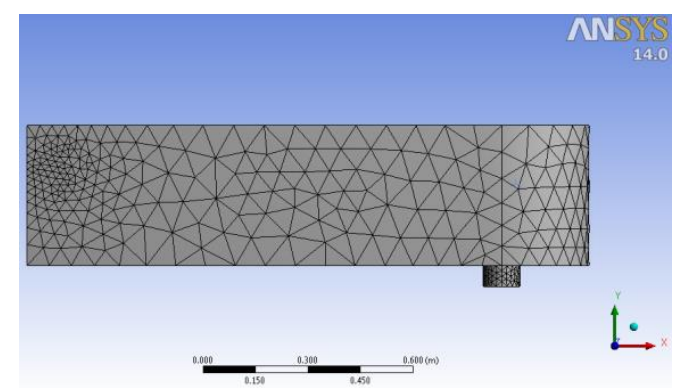

Gambar 4. Hasil Meshing

Pada gambar diatas, proses meshing dilakukan pada kondisi pengaturan standart (default) dimana ukuran mesh diatur sedemikian rupa sehingga diperoleh hasil yang teliti dan daya komputasi yang dibutuhkan tidak terlalu besar.

\section{Proses Solving}

\section{a. Menentukan Jenis Aliran}

Fluida yang digunakan dalam simulasi ini adalah air dan udara dengan sifat-sifat sebagai berikut :

1. Air

- Kerapatan (densitas) konstan, $\rho=998.2 \mathrm{~kg} / \mathrm{m}^{3}$

$\circ$ Viskositas, $\mu=0.001003$ Pa.s

2. Udara

○ Kerapatan (densitas) konstan, $\rho=1.225 \mathrm{~kg} / \mathrm{m}^{3}$

○ Viskositas, $\mu=1.7894 \mathrm{e}-05$ Pa.s

Aliran yang digunakan dalam simulasi ini adalah turbulen, karena mengacu pada aliran air yang berputar dan tidak dapat diprediksi. Dari asumsi fluida yang digunakan adalah dengan temperatur dan densitas tetap sehingga jenis alirannya isotermal dan inkompresibel.

\section{b. Menetukan Kondisi Batas}

Penentuan kondisi batas pada model turbin vortex dapat dilihat dari gambar 5. 


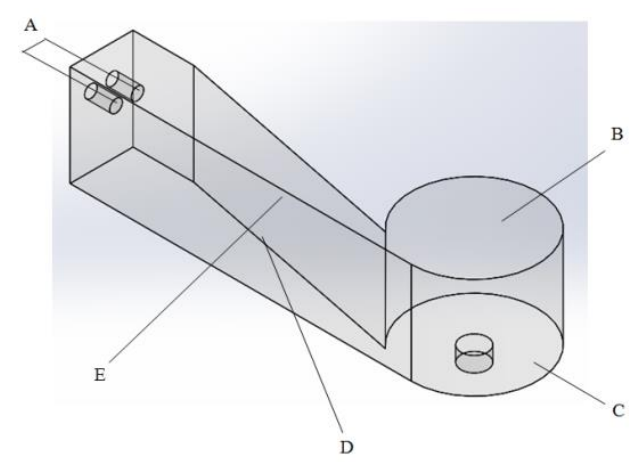

Gambar 5. Kondisi Batas pada Turbin Vortex

Pada gambar diatas, simbol-simbol tersebut merupakan batas-batas yang diberikan agar hasil simulasi menjadi akurat dan mendekati kondisi yang sebenarnya. Simbol tersebut dapat dilihat pada tabel 2 .

Tabel 2. Kondisi Batas Turbin Vortex

\begin{tabular}{|c|c|c|c|}
\hline $\begin{array}{c}\text { Sim } \\
\text { bol }\end{array}$ & $\begin{array}{c}\text { Kondi } \\
\text { si } \\
\text { Batas }\end{array}$ & Jenis & Nilai \\
\hline A & Inlet & $\begin{array}{c}\text { Velocit } \\
\text { Inlet }\end{array}$ & $\begin{array}{c}\text { (Disesuaik } \\
\text { an) }\end{array}$ \\
\hline B & Atas & $\begin{array}{c}\text { Pressur } \\
\text { e Outlet }\end{array}$ & $\begin{array}{c}\text { O Pa } \\
\text { (Gauge })\end{array}$ \\
\hline $\mathrm{C}$ & Outlet & $\begin{array}{c}\text { Pressur } \\
\text { e Outlet }\end{array}$ & $\begin{array}{c}\text { O Pa } \\
(\text { Gauge })\end{array}$ \\
\hline $\mathrm{D}$ & $\begin{array}{c}\text { Bawa } \\
\mathrm{h}\end{array}$ & Wall & - \\
\hline $\mathrm{E}$ & $\begin{array}{c}\text { Dindi } \\
\mathrm{ng}\end{array}$ & Wall & - \\
\hline
\end{tabular}

\section{c. Pengaturan Simulasi (Simulation Setting)}

Pengaturan simulasi yang dimaksud adalah menetukan beberapa aspek yang diperlukan dalam simulasi seperti bentuk solver yang dipilih, material fluida, jenis viskos, dll sesuai dengan asumsi yang dilakukan. Tabel 3 menunjukkan pengaturan simulasi yang dilakukan di dalam FLUENT.

Tabel 3. Pengaturan Simulasi

\begin{tabular}{|c|c|}
\hline Aspek & Pengaturan \\
\hline \multicolumn{2}{|l|}{ Solver } \\
\hline Model & Pressure based, $3 D$, transient \\
\hline Multifasa (Multiphase) & Volume of Fluid (VOF) \\
\hline
\end{tabular}




\begin{tabular}{|c|c|} 
Viskos (Viscous Model) & Turbulent $\mathrm{k}-\varepsilon$ Standard \\
\hline \multirow{2}{*}{ Material } & Water-liquid \\
\cline { 2 - 2 } & $\rho=998.2 \mathrm{~kg} / \mathrm{m}^{3}$ \\
\hline \multirow{2}{*}{ Kondisi Operasi (Operating Condition) } & Air \\
\cline { 2 - 2 } & $\rho=1.225 \mathrm{~kg} / \mathrm{m}^{3}$ \\
\hline Inisiasi (Initialize) & Velocity Inlet \\
\hline Residual Monitor & $10^{3}$ \\
\hline
\end{tabular}

\section{Menjalankan Simulasi}

Setelah proses pre-processor dan solution telah selesai diatur, maka simulasi dimulai (run) hingga solusi yang konvergen tercapai.

\section{HASIL DAN PEMBAHASAN}

Proses pengambilan sampel kecepatan dilakukan dengan membentuk 4 garis dengan 1 pusat seperti gambar 6 .

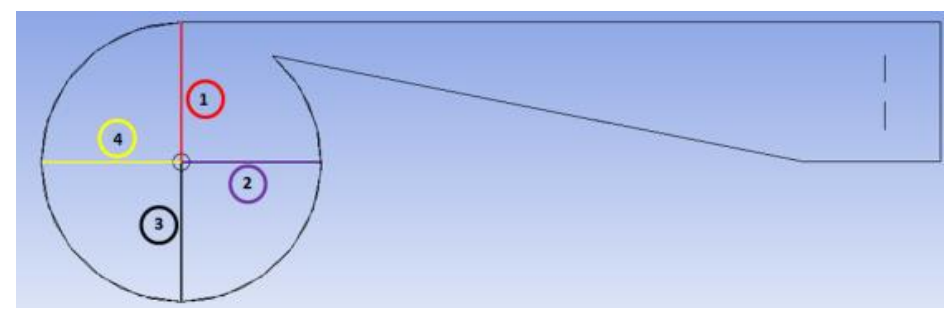

Gambar 6. Distribusi Kecepatan Dengan 4 Garis Sepusat

Garis berwarna merah menunjukan garis 1. Garis berwarna ungu menunjukan garis

2. Garis berwarna hitam menunjukan garis 3. Garis berwarna kuning menunjukan garis 4. Dari keempat garis tersebut didapat distribusi kecepatan dengan 10 titik pada tiap garis.

\section{Lubang Buang 1}

Dari hasil simulasi didapat kecepatan inlet $0.15 \mathrm{~m} / \mathrm{s}$ dan head $0.1 \mathrm{~m}$ seperti gambar 7.

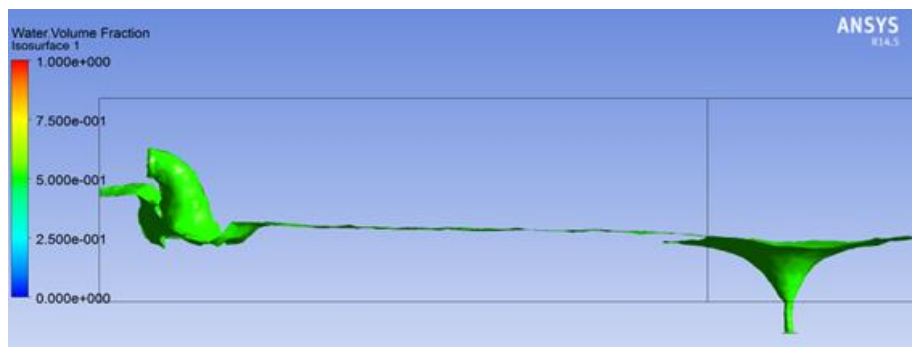

Gambar 7. Hasil Simulasi Lubang Buang 1 
Pada gambar diatas, yang berwarna hijau pada model turbin vortex menunjukan permukaan air. Pada sebelah kiri model turbin vortex merupakan tingkatan water volume fraction. Hasil distribusi kecepatan dapat dilihat pada gambar 8 .

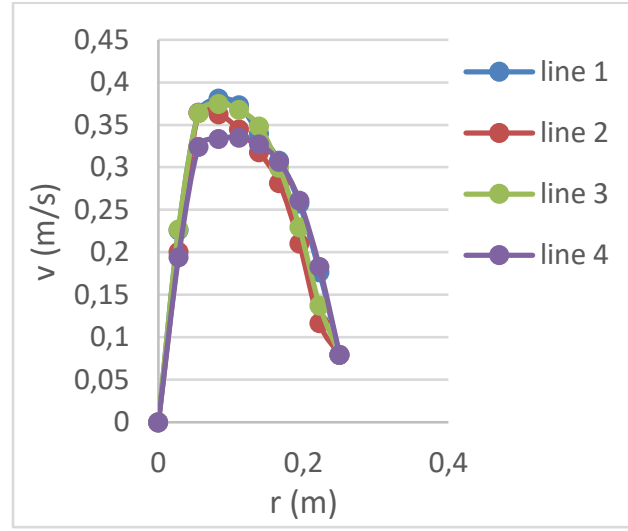

Gambar 8. Grafik Distribusi Kecepatan Pada Lubang Buang 1

Dari grafik diatas didapat kecepatan maksimum $0.38094 \mathrm{~m} / \mathrm{s}$ pada garis 1 .

\section{Lubang Buang 2}

Dari hasil simulasi didapat kecepatan inlet $0.6 \mathrm{~m} / \mathrm{s}$ dan head $0.17 \mathrm{~m}$ seperti gambar 9.

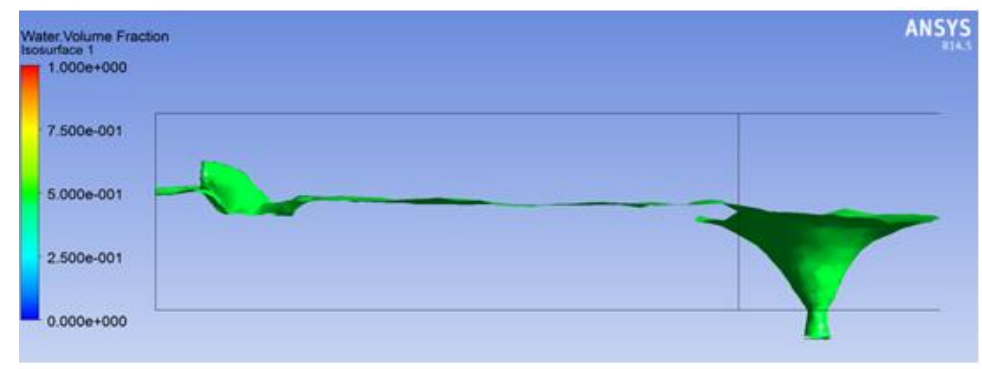

Gambar 9. Hasil Simulasi Lubang Buang 2

Pada gambar diatas, yang berwarna hijau pada model turbin vortex menunjukan permukaan air. Pada sebelah kiri model turbin vortex merupakan tingkatan water volume fraction. Hasil distribusi kecepatan dapat dilihat pada gambar 10. 


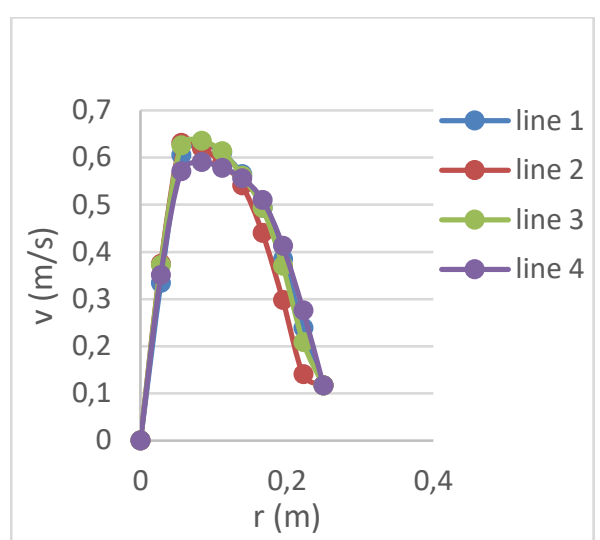

Gambar 10. Grafik Distribusi Kecepatan Pada Lubang Buang 2

Dari grafik diatas didapat kecepatan maksimum $0.63545 \mathrm{~m} / \mathrm{s}$ pada garis 3 .

\section{Lubang Buang 3}

Dari hasil simulasi didapat kecepatan inlet $1.5 \mathrm{~m} / \mathrm{s}$ dan head $0.28 \mathrm{~m}$ seperti gambar 11.

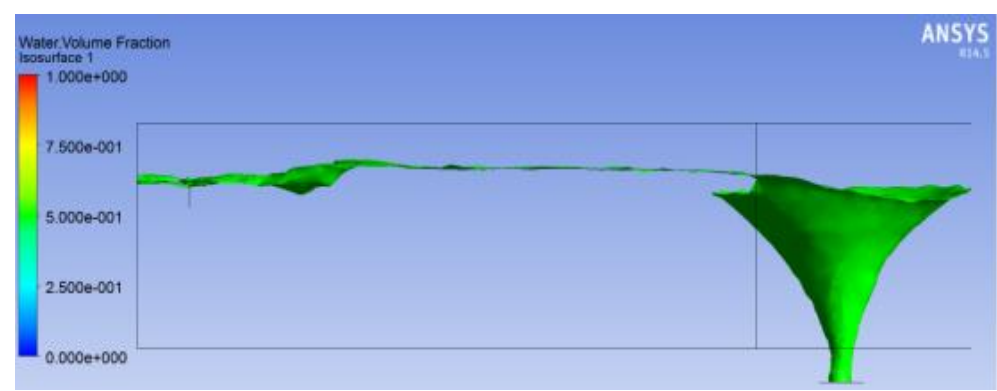

Gambar 11. Hasil Simulasi Lubang Buang 3

Pada gambar diatas, yang berwarna hijau pada model turbin vortex menunjukan permukaan air. Pada sebelah kiri model turbin vortex merupakan tingkatan water volume fraction. Hasil distribusi kecepatan dapat dilihat pada gambar 12 .

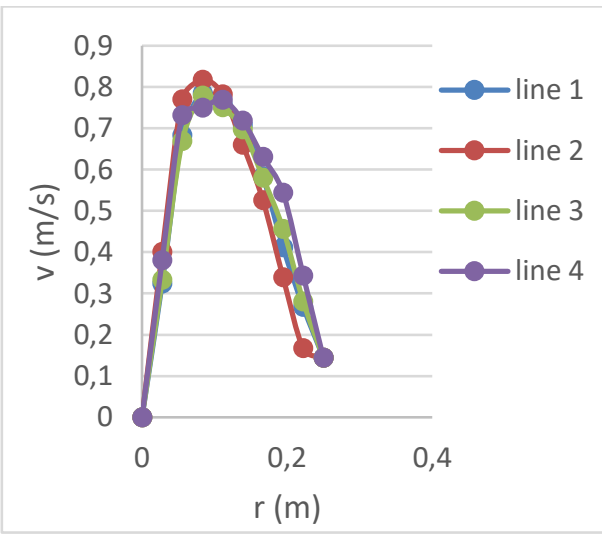

Gambar 12. Grafik Distribusi Kecepatan Pada Lubang Buang 3

Dari grafik diatas didapat kecepatan maksimum $0.81703 \mathrm{~m} / \mathrm{s}$ pada garis 2 . 


\section{Lubang Buang 4}

Dari hasil simulasi didapat kecepatan inlet $2 \mathrm{~m} / \mathrm{s}$ dan head $0.29 \mathrm{~m}$ seperti gambar 13.

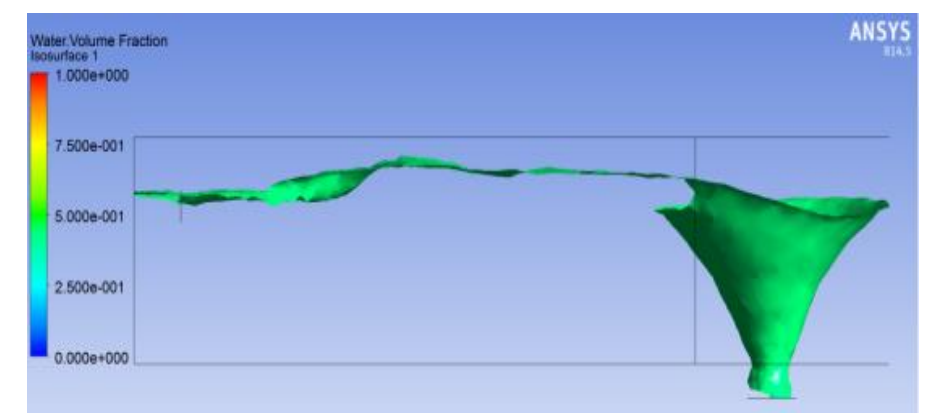

Gambar 13. Hasil Simulasi Lubang Buang 4

Pada gambar diatas, yang berwarna hijau pada model turbin vortex menunjukan permukaan air. Pada sebelah kiri model turbin vortex merupakan tingkatan water volume fraction. Hasil distribusi kecepatan dapat dilihat pada gambar 14.

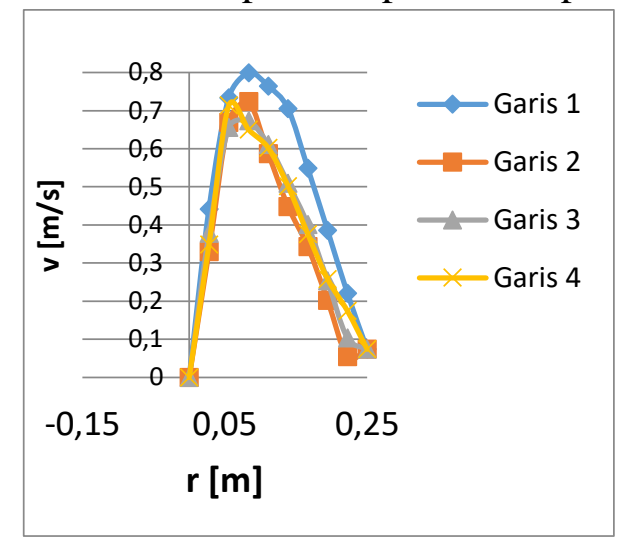

Gambar 14. Grafik Distribusi

Kecepatan Pada Lubang Buang 4

Dari grafik diatas didapat kecepatan maksimum $0.79887 \mathrm{~m} / \mathrm{s}$ pada garis 1 .

\section{Lubang Buang 5}

Dari hasil simulasi didapat kecepatan inlet $3 \mathrm{~m} / \mathrm{s}$ dan head $0.30 \mathrm{~m}$ seperti gambar 15.

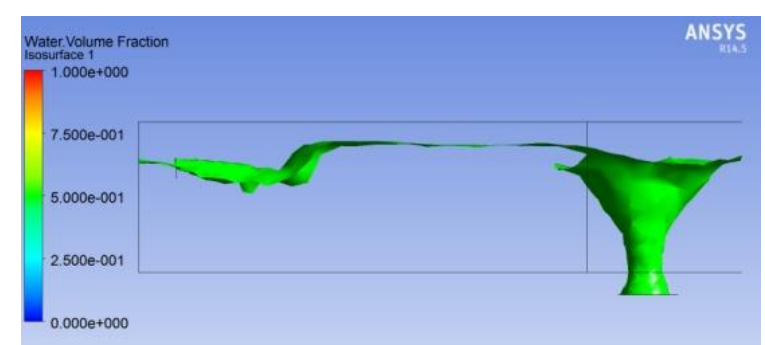

Gambar 15. Hasil Simulasi Lubang Buang 5 
Pada gambar diatas, yang berwarna hijau pada model turbin vortex menunjukan permukaan air. Pada sebelah kiri model turbin vortex merupakan tingkatan water volume fraction. Hasil distribusi kecepatan dapat dilihat pada gambar 16.

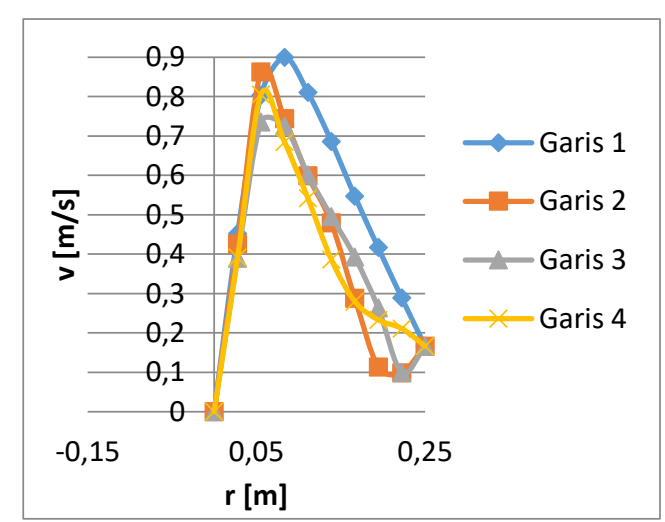

Gambar 16. Grafik Distribusi Kecepatan Pada Lubang Buang 5

Dari grafik diatas didapat kecepatan maksimum $0.89998 \mathrm{~m} / \mathrm{s}$ pada garis 1 .

\section{Analisa Daya Pada Rumah Turbin Vortex}

Dari hasil analisa, didapat debit dan daya air pada tabel 4 dan tabel 5 sesuai hasil simulasi turbin vortex.

Tabel 4. Debit Pada Tiap Lubang Buang

\begin{tabular}{|c|c|c|c|}
\hline \multirow{2}{*}{ Lubang Buang ke- } & $\begin{array}{c}\text { Kecepatan rata-rata } \\
(\mathrm{m} / \mathrm{s})\end{array}$ & Luas Permukaan & Debit \\
\cline { 3 - 4 } & 0.239 & $\left(\mathrm{~m}^{2}\right)$ & $\left(\mathrm{m}^{3 /} / \mathrm{s}\right)$ \\
\hline 1 & 0.392203 & 0.000707 & 0.000168973 \\
\hline 2 & 0.4742167 & 0.002375 & 0.000931482 \\
\hline 2 & 0.38654878 & 0.008655 & 0.00334558 \\
\hline 4 & 0.410711703 & 0.020096 & 0.008253662 \\
\hline 5 & &
\end{tabular}

Tabel 5. Daya Air Hasil Simulasi

\begin{tabular}{|c|c|c|c|c|c|}
\hline \multirow{2}{*}{$\begin{array}{c}\text { Lubang } \\
\text { Buang ke- }\end{array}$} & $\rho$ air & $\mathrm{g}$ & $\mathrm{Q}$ & $\mathrm{H}$ & Pair \\
\cline { 2 - 6 } & $\left(\mathrm{kg} / \mathrm{m}^{3}\right)$ & $\left(\mathrm{m} / \mathrm{s}^{2}\right)$ & $\left(\mathrm{m}^{3} / \mathrm{s}\right)$ & $(\mathrm{m})$ & (Watt) \\
\hline 1 & \multirow{3}{*}{998.2} & \multirow{3}{*}{9.81} & 0.000168973 & 0.1 & 0.16546414 \\
\cline { 1 - 3 } \cline { 4 - 6 } & & & 0.000931482 & 0.17 & 1.550636353 \\
\cline { 1 - 3 } & & & 0.002689757 & 0.28 & 7.374925723 \\
\hline
\end{tabular}




\begin{tabular}{|l|l|c|c|c|}
4 & 0.00334558 & 0.29 & 9.500708429 \\
\hline 5 & & 0.008253662 & 0.3 & 24.24680432 \\
\hline
\end{tabular}

Perbandingan Daya Hasil Simulasi Terhadap Daya Hasil Teoritis Dan Daya Hasil Eksperimen

Perbandingan daya tersebut dapat dilihat pada gambar 17.

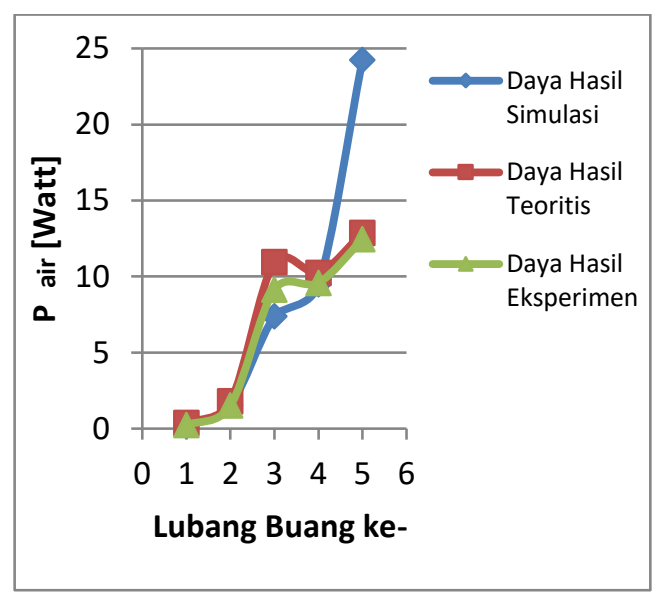

Gambar 17. Grafik Perbandingan Daya Hasil Simulasi Terhadap Daya Hasil Teoritis Dan Daya Hasil Eksperimen

Dari grafik diatas didapat daya maksimum 24.24680432 watt pada daya hasil simulasi dilubang buang 5 dan daya minimum 0.16546414 watt pada daya hasil simulasi dilubang buang 1 .

\section{Kesimpulan}

Berdasarkan hasil dan pembahasan dapat ditarik kesimpulan sebagai berikut:

1. Metode Computational Fluid Dynamic (CFD) dapat memprediksi dengan efisien dan efektif pada turbin vortex.

2. Kecepatan rata-rata yang didapat dari hasil simulasi CFD adalah
a. Pada lubang buang 1 adalah $0.239 \mathrm{~m} / \mathrm{s}$.
b. Pada lubang buang 2 adalah $0.392203 \mathrm{~m} / \mathrm{s}$.
c. Pada lubang buang 3 adalah $0.4742167 \mathrm{~m} / \mathrm{s}$.
d. Pada lubang buang 4 adalah $0.38654878 \mathrm{~m} / \mathrm{s}$.
e. Pada lubang buang 5 adalah $0.410711703 \mathrm{~m} / \mathrm{s}$.

3. Daya air yang didapat dari hasil simulasi CFD adalah 

a. Pada lubang buang 1 adalah 0.16546414 watt.
b. Pada lubang buang 2 adalah 1.550636353 watt.
c. Pada lubang buang 3 adalah 7.374925723 watt.
d. Pada lubang buang 4 adalah 9.500708429 watt.
e. Pada lubang buang 5 adalah 24.24680432 watt.

\section{DAFTAR PUSTAKA}

[1] Contaned Energy Indonesia. Buku Panduan Energi Yang Terbarukan. PNPM Mandiri.

[2] Muson, Bruce, R., Young, Donald, F., Okiishi, Theodore, H., "Fundamentals Of Fluid Mechanics Fifth Edition”. Jhon Wiley \& Sons, Inc.,2006.

[3] Prof. B.S. Thandaveswara, "Hydraulics: Rotational and Irrotational Flow", Indian Institute of Thechnology Madras.

[4] Sujate Wanchat, Ratchaphon Suntivarakorn, Sujin Wanchat, Kitipong Tonmit, and Pongpun Kayanyiem, "A Parametric Study of a Gravitation Vortex Power Plant”, Khonkaen University, Khonkaen, Thailand, 2013.

[5] Tuakia, Firman. 2008. Dasar-dasar CFD Menggunakan Fluent. Bandung: Informatika Bandung.

[6] Ansys 14.0 Help, (C) 2011 SAS IP, Inc 